\title{
Developmental Changes in Rabbit Juxtamedullary Proximal Convoluted Tubule Bicarbonate Permeability
}

\author{
RAYMOND QUIGLEY AND MICHEL BAUM \\ Department of Pediatrics, University of Texas Southwestern Medical Center at Dallas, Dallas, Texas 75235-9063
}

\begin{abstract}
The bicarbonate transport rate in neonatal rabbit juxtamedullary proximal convoluted tubules (JMPCT) is lower than that in adults. The reduced rate of transport could be due to a decrease in active bicarbonate transport or an increase in the passive permeability of the tubule to bicarbonate. The present in vitro microperfusion study directly measured the bicarbonate permeability of neonatal and adult JMPCT. Bicarbonate permeability was measured at both slow and fast perfusion rates to simulate the neonatal and adult proximal tubule flow rates, respectively. At $38^{\circ} \mathrm{C}$ in tubules perfused at $3 \mathrm{~nL} / \mathrm{min}$, bicarbonate permeability was $0.29 \pm 0.11 \times 10^{-5} \mathrm{~cm} / \mathrm{s}$ in neonates and $1.70 \pm 0.49 \times 10^{-5} \mathrm{~cm} / \mathrm{s}$ in adult PCT $(p<0.05)$. At a perfusion rate of $10 \mathrm{~nL} / \mathrm{min}$, bicarbonate permeability was $0.11 \pm 0.27 \times 10^{-5} \mathrm{~cm} / \mathrm{s}$ in neonatal PCT and $2.31 \pm 0.15$ $\times 10^{-5} \mathrm{~cm} / \mathrm{s}$ in adult PCT $(p<0.05)$. These results demonstrate that bicarbonate permeability in neonatal JMPCT is significantly lower than that in adult JMPCT. Thus, the lower rate of bicarbonate transport in neonatal PCT is entirely due to a lower rate of active bicarbonate transport. (Pediatr Res 28: 663-666, 1990)
\end{abstract}

\section{Abbreviations}

PCT, proximal convoluted tubule

JM, juxtamedullary

$\mathrm{PD}$, potential difference

$\mathrm{T}_{\mathrm{CO}_{2}}$, total $\mathrm{CO}_{2}$

$\mathrm{P}_{\mathrm{HCO}_{3}}$, bicarbonate permeability

The adult proximal tubule reabsorbs $80 \%$ of the filtered bicarbonate. Net bicarbonate absorption is due to active transcellular proton secretion and passive paracellular bicarbonate diffusion. The preferential reabsorption of bicarbonate over chloride ions by the proximal tubule results in the generation of a bicarbonate concentration gradient between the tubular lumen and blood. At the end of the PCT, the bicarbonate concentration of the luminal fluid is $8 \mathrm{mmol} / \mathrm{L}$ (1). The rate of passive back-diffusion of bicarbonate is determined by the lumen to blood concentration gradient and the bicarbonate permeability. Thus, a lower rate of bicarbonate transport may be due to a decreased rate of active transport or an increased bicarbonate permeability resulting in enhanced bicarbonate diffusion back into the tubular lumen.

Clearance studies have suggested that the bicarbonate reabsorptive capacity is lower in neonatal proximal tubules (2).

Received April 6, 1990; accepted August 8, 1990

Correspondence and reprint requests: Michel Baum, M.D., Department of Pediatrics, University of Texas Southwestern Medical Center at Dallas, 5323 Harry Hines Blvd., Dallas, TX 75235-9063.

Supported by NIH Grants R29-DK38465-01 and DK41612-01 and a grant from the American Heart Association (no. 890664).
Schwartz and Evan (3) directly measured bicarbonate transport in postnatal rabbits using in vitro microperfusion. Net bicarbonate absorption was $1 / 3$ that measured in adult animals during the first 3 to $4 \mathrm{wk}$ after birth. Adult rates of transport were measured by $6 \mathrm{wk}$ of age. These developmental changes in bicarbonate reabsorption could be due to maturation in either the rate of proton secretion or bicarbonate permeability.

Recently, it has been postulated that newborn animals have a high proximal tubule solute permeability (4). The urinary recovery of mannitol microinjected into an early proximal tubule segment in guinea pigs increased from $92 \%$ at birth to $100 \%$ at $49 \mathrm{~d}$ of age. The urinary recovery of larger molecules such as creatinine and inulin did not change with age. Although these studies suggest that changes in proximal tubule permeability may be an important maturational phenomenon, solute permeability in the proximal tubule has not been directly measured. The purpose of the present in vitro microperfusion study was to directly measure JMPCT bicarbonate permeability to determine if it is a factor in the maturation of bicarbonate transport.

\section{MATERIALS AND METHODS}

Isolated segments of rabbit JMPCT were dissected and perfused as previously described $(5,6)$. Briefly, kidneys from adult and newborn $(7+1 \mathrm{~d}$ old) New Zealand White rabbits were cut in coronal slices. Individual $S_{1}$ and early $S_{2}$ JMPCT were dissected in cooled $\left(4^{\circ} \mathrm{C}\right)$ ultrafiltrate-like solution containing (in mM) $115 \mathrm{NaCl}, 25 \mathrm{NaHCO}_{3}, 2.3 \mathrm{Na}_{2} \mathrm{HPO}_{4}, 10 \mathrm{Na}$ acetate, 1.8 $\mathrm{CaCl}_{2}, 1 \mathrm{MgSO}_{4}, 5 \mathrm{KCl}, 8.3$ glucose, and 5 alanine. 'Tubules were transferred to a thermostatically controlled 1.2-mL bath chamber and were perfused using concentric glass pipettes. Temperature was controlled at either 20 or $38^{\circ} \mathrm{C}$. The bathing solution was an ultrafiltrate-like solution with $6 \mathrm{~g} \%$ albumin. All solutions were bubbled with $95 \% \mathrm{O}_{2} / 5 \% \mathrm{CO}_{2}$.

The perfusate was designed to yield a volume absorption rate and a transepithelial PD of zero. It contained (in mM) $105 \mathrm{NaCl}$, $5 \mathrm{NaHCO}_{3}, 1 \mathrm{Na}_{2} \mathrm{HPO}_{4}, 1.2 \mathrm{CaCl}_{2}, 1 \mathrm{MgSO}_{4}, 5 \mathrm{KCl}, 10$ mannitol, and $30 \mathrm{Na}$ gluconate. Thus, this solution was similar to the ultrafiltrate-like solution except that mannitol replaced the glucose and alanine and the gluconate was substituted for the acetate and most of the bicarbonate. With the removal of these solutes, volume absorption and PD are decreased to zero (6). The bicarbonate concentration was reduced in the perfusate to impose a bath to lumen bicarbonate concentration gradient. Acetazolamide $(1 \mathrm{mM})$ was added to both the bathing solution and the luminal perfusate to inhibit active bicarbonate transport. Thus, transport of bicarbonate was only due to passive diffusion down its concentration gradient from the bath into the lumen.

${ }^{1} S_{1}$ and early $S_{2}$ PCT were used in our study. Liu and Cogan (7) have demonstrated that bicarbonate permeability in $\mathrm{S}_{1} \mathrm{PCT}$ was 5 -fold higher than $\mathrm{S}_{2}$ PCT in Munich-Wistar rats using in vivo microperfusion. Separate measurements of $S_{1}$ and $S_{2}$ PCT bicarbonate permeability were not technically possible in our study. 
The transepithelial PD was measured by using the perfusion pipette as the bridge into the tubular lumen. The perfusate was connected to the recording calomel half cell by a bridge containing perfusate in series with a $3.6 \mathrm{M} \mathrm{KCl} / 0.9 \mathrm{M} \mathrm{KNO}_{3}$ agarose bridge. The bathing solution was initially connected to the reference calomel half cell by a bridge containing the perfusate in series with a $3.6 \mathrm{M} \mathrm{KCl} / 0.9 \mathrm{M} \mathrm{KNO}_{3}$ agarose bridge. Before the tubule was transferred and perfused, the bath chamber was filled with the perfusate and the electrometer was zeroed. The bath chamber and bridge were then refilled with the ultrafiltrate-like solution and the liquid junction potential was measured and subtracted from the PD recorded during the experimental protocol.

Net volume absorption rate $(\mathrm{nL} / \mathrm{min} \cdot \mathrm{mm})$ was measured as the difference between the perfusion and collection rates (nL/ min) and normalized per $\mathrm{mm}$ of tubule length. Exhaustively dialyzed [methoxy $-{ }^{3} \mathrm{H}$ ] inulin was added to the perfusate at a concentration of $50 \mu \mathrm{Ci} / \mathrm{mL}$ so that the perfusion rate could be calculated. The collection rate was determined from timed collections in a constant volume pipette. The length, in $\mathrm{mm}$, and the inner radius, in $\mu \mathrm{m}$, were measured with an eyepiece micrometer.

$\mathrm{T}_{\mathrm{CO}_{2}}$ was measured by microcalorimetry (8). $\mathrm{T}_{\mathrm{CO}_{2}}$ includes bicarbonate, dissolved $\mathrm{CO}_{2}$, and carbonate. Under the conditions used, $\mathrm{T}_{\mathrm{CO}_{2}}$ is an excellent estimate of the bicarbonate concentration. To measure any potential $\mathrm{T}_{\mathrm{CO}_{2}}$ losses, separate experiments were performed where the perfusion pipette was threaded directly into the collecting pipette. Perfusion rates in these experiments were identical to those of the tubule experiments to ensure that the collected fluid would be in contact with the $N$-2-hydroxyethylpiperazine- $N^{\prime}$-2-ethanesulfonic acid-equilibrated oil for the same amount of time. There was an average of five measurements at each perfusion rate. At the slow perfusion rate $(3 \mathrm{~nL} /$ min), the perfusion $\mathrm{T}_{\mathrm{CO}_{2}}$ was $5.0 \pm 0.2 \mathrm{mmol} / \mathrm{L}$ and at the fast perfusion rate $(10 \mathrm{~nL} / \mathrm{min})$ it was $4.8 \pm 1.1 \mathrm{mmol} / \mathrm{L}$.

The bicarbonate permeability was calculated from the following equation (9):

$$
\mathrm{P}_{\mathrm{HCO}_{3}}=\frac{\mathrm{V}_{\mathrm{L}}}{\mathrm{L}} \ln \frac{\left(\mathrm{C}_{\mathrm{O}}-\mathrm{C}_{\mathrm{B}}\right)}{\left(\mathrm{C}_{\mathrm{L}}-\mathrm{C}_{\mathrm{B}}\right)}
$$

where $C_{O}, C_{L}$, and $C_{B}$ represent the $T_{C_{2}}$ (in mmol/L) in the perfusate, collected fluid, and bathing fluid, respectively, and $\mathrm{V}_{\mathrm{L}}$ is the collection rate in $\mathrm{nL} / \mathrm{min}$. The units were changed to $\mathrm{cm} / \mathrm{s}$ by using the measured inner radius to calculate the luminal surface area.

There were three experimental conditions in which the bicarbonate permeability was determined. In most experiments, tubules were first perfused at a slow perfusion rate $(3 \mathrm{~nL} / \mathrm{min})$ at $20^{\circ} \mathrm{C}$. Next, the tubules were warmed to $38^{\circ} \mathrm{C}$ with the perfusion rate remaining the same. During the last period, the perfusion rate was increased to $10 \mathrm{~nL} / \mathrm{min}$ with the temperature remaining at $38^{\circ} \mathrm{C}$. The tubules were initially perfused at the slow perfusion rate because the single nephron GFR of neonatal rabbits is lower than that of adults $(10,11)$. Also, the slower perfusion rate would allow for a maximal increase in the bicarbonate concentration of the collected fluid so that a small bicarbonate permeability could be accurately measured. This perfusion rate also simulates that the used by Schwartz and Evan (3) when perfusing rabbit neonatal JMPCT. The tubules were cooled to $20^{\circ} \mathrm{C}$ to ensure that active transport was inhibited and then warmed to $38^{\circ} \mathrm{C}$ so that measurements could be made at a physiologic temperature as well. Thus, most tubules were examined under the three conditions studied. Proximal tubules are viable for hours under these conditions $(3,5,6,9)$. There was a minimum of three determinations of collected bicarbonate in each period and a minimum of two determinations of net volume absorption. Each data point is the mean of these determinations.

All results are given as the mean \pm SEM. The $t$ test for unpaired data was used to determine statistical significance.

\section{RESULTS}

The first series of experiments examined whether there was a difference in bicarbonate permeability at $20^{\circ} \mathrm{C}$. These results are shown in Table 1 and Figure 1. Tubules were cooled to ensure that active transport was inhibited. The perfusion rate was maintained between 3 and $4 \mathrm{~nL} / \mathrm{min}$. The bicarbonate permeability was $0.43 \pm 0.20 \times 10^{-5} \mathrm{~cm} / \mathrm{s}$ in the neonatal PCT and $1.95 \pm$ $0.63 \times 10^{-5} \mathrm{~cm} / \mathrm{s}$ in the adult PCT $(p=0.05)$.

The second set of experiments examined whether there was a difference in the bicarbonate permeability at the physiologic temperature of $38^{\circ} \mathrm{C}$. These results are shown in Table 1 and Figure 2. The perfusion rate remained at the slow rate used above. The bicarbonate permeability was $0.29 \pm 0.11 \times 10^{-5}$ $\mathrm{cm} / \mathrm{s}$ for the neonatal PCT and $1.70 \pm 0.49 \times 10^{-5} \mathrm{~cm} / \mathrm{s}$ for the adult PCT $(p<0.05)$.

The last series of experiments was designed to determine whether there was a difference in bicarbonate permeability at a higher perfusion rate. The perfusion rate was increased to $10 \mathrm{~nL} /$ min to simulate perfusion rates used in transport studies in in vitro microperfusion studies using PCT from adult rabbits. The bicarbonate permeability was $0.11 \pm 0.27 \times 10^{-5} \mathrm{~cm} / \mathrm{s}$ in the neonatal PCT and $2.31 \pm 0.85 \times 10^{-5} \mathrm{~cm} / \mathrm{s}$ for the adult PCT $(p<0.05)$. These results are shown in Table 1 and Figure 3 . The bicarbonate permeability was slightly higher at the faster rate in adults as previously described $(12,13)$. Bicarbonate permeability was lower in newborn PCT, demonstrating that neonatal PCT lack a flow-dependent increase in bicarbonate permeability at faster perfusion rates. This difference, however, was not statistically significant.

\section{DISCUSSION}

Our in vitro microperfusion study directly examined bicarbonate permeability of neonatal and adult JMPCT. Tubules were perfused initially at $20^{\circ} \mathrm{C}$ to ensure that active transport was inhibited and were then warmed to the physiologic temperature of $38^{\circ} \mathrm{C}$. The perfusion rate was initially slow $(3 \mathrm{~nL} / \mathrm{min})$ to simulate neonatal single nephron GFR and to allow for a maximal increase in luminal bicarbonate concentration. The perfusion rate was then increased to $10 \mathrm{~nL} / \mathrm{min}$ to simulate the perfusion rates used in in vitro microperfusion studies in PCT from adult rabbits. Under all of the experimental conditions tested, the collected bicarbonate concentration from the neonatal JMPCT was significantly lower than that from the adult JMPCT. The difference in collected bicarbonate concentrations could not be a result of differences in tubule length or inner radius between the two groups because these parameters were not different. These results demonstrate that bicarbonate permeability is lower in newborn than in adult PCT.

Schwartz and Evan (3) found the rate of net bicarbonate transport in adult and neonatal PCT to be 89.4 and $26.6 \mathrm{pmol} /$ $\mathrm{mm} \cdot \mathrm{min}$, respectively. Net bicarbonate flux is composed of active bicarbonate reabsorption and passive back-diffusion. Using our permeability data, passive back-diffusion of bicarbonate accounted for $2.6 \mathrm{pmol} / \mathrm{mm} \cdot \mathrm{min}$ in adult and only 0.3 $\mathrm{pmol} / \mathrm{mm} \cdot \mathrm{min}$ of the net flux in neonatal PCT. Thus, bicarbonate permeability is not a factor in the lower rate of bicarbonate transport in neonatal PCT.

The bicarbonate permeability measured in adult JMPCT in our study agrees closely with previously published studies. Sasaki et al. (9) measured the $\mathrm{P}_{\mathrm{HCO}_{3}}$ of adult PCT by perfusing the tubules with $40 \mathrm{mmol} / \mathrm{L}$ of bicarbonate and bathing them with $25 \mathrm{mmol} / \mathrm{L}$ of bicarbonate. The tubules were perfused at 3-4 $\mathrm{nL} / \mathrm{min}$ at $20^{\circ} \mathrm{C}$. Ethoxazolamide was added to inhibit active bicarbonate transport. Their result of $1.09 \times 10^{-7} \mathrm{~cm}^{2} / \mathrm{s}$ is equivalent to $1.51 \times 10^{-5} \mathrm{~cm} / \mathrm{s}$ using an inner radius of 11.5 $\mu \mathrm{m}$. Holmberg et al. (14) perfused adult JMPCT with $4 \mathrm{mmol} /$ $\mathrm{L}$ of bicarbonate and bathed the tubules with $24 \mathrm{mmol} / \mathrm{L}$ of bicarbonate to measure the $\mathrm{P}_{\mathrm{HCO}_{3}}$ of JMPCT. They perfused the tubules at $7-10 \mathrm{~nL} / \mathrm{min}$ at $21^{\circ} \mathrm{C}$ and found the $\mathrm{P}_{\mathrm{HCO}_{3}}$ to be 2.33 
Table 1. Results of perfusing neonatal and adult JMPCT*

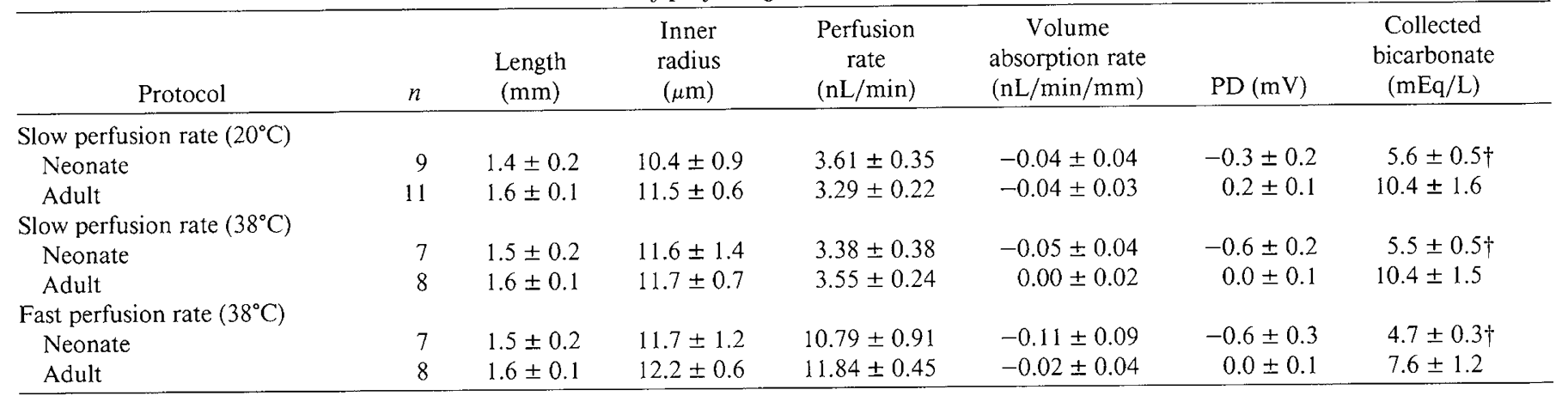

* Values are mean \pm SEM.

$\uparrow$ Different from adult value at $p<0.05$.

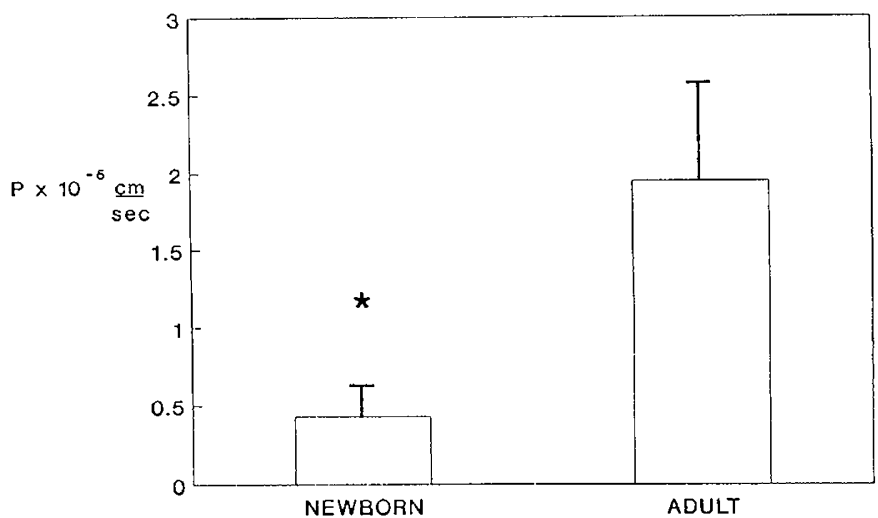

$\cdot p=0.05$

Fig. 1. Bicarbonate permeability in neonatal and adult JMPCT perfused at $3 \mathrm{~nL} / \mathrm{min}$ and $20^{\circ} \mathrm{C}(p=0.05)$.

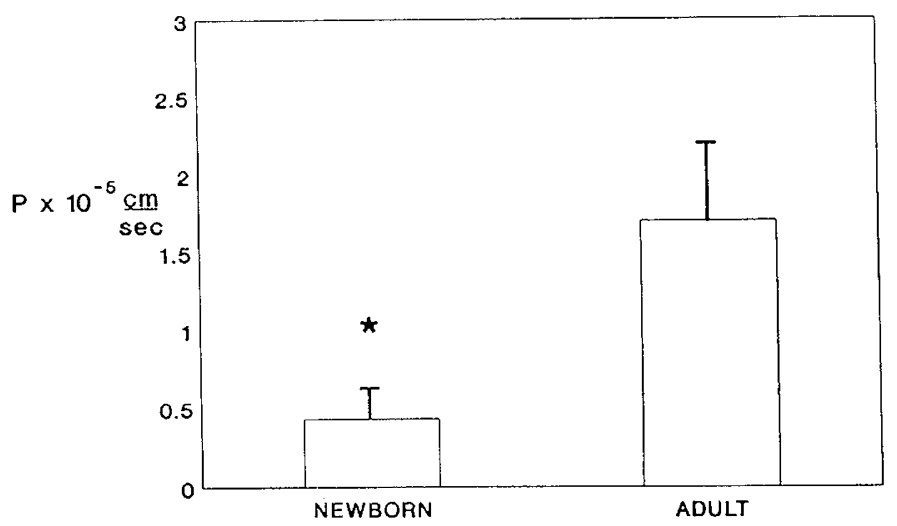

p.0.05

Fig. 2. Bicarbonate permeability in neonatal and adult JMPCT perfused at $3 \mathrm{~nL} / \mathrm{min}$ and $38^{\circ} \mathrm{C}(p<0.05)$.

$\times 10^{-5} \mathrm{~cm} / \mathrm{s}$. Using a similar protocol to the one employed in this study, Salmon and Baum (6) found the bicarbonate permeability of adult PCT to be $1.8 \times 10^{-5} \mathrm{~cm} / \mathrm{s}$ at $38^{\circ} \mathrm{C}$ at a perfusion rate of $8-10 \mathrm{~nL} / \mathrm{min}$.

Previous studies by Liu and Cogan (13) have demonstrated flow dependence of bicarbonate permeability in the $S_{1}$ superficial rat PCT using in vivo microperfusion. In this study, increasing the perfusion rate from 30 to $61 \mathrm{~nL} / \mathrm{min}$ resulted in a significant increase in bicarbonate permeability from $20.4 \pm 1.8 \times 10^{-7}$ $\mathrm{cm}^{2} / \mathrm{s}$ to $54.0 \pm 1.1 \times 10^{-7} \mathrm{~cm}^{2} / \mathrm{s}$. We also found a tendency for bicarbonate permeability to increase in adult PCT when the perfusion rate was increased. Bicarbonate permeability was 1.70 $\pm 0.49 \times 10^{-5} \mathrm{~cm} / \mathrm{s}$ at a perfusion rate of $3.55 \mathrm{~nL} / \mathrm{min}$ and 2.31 $\pm 0.85 \times 10^{-5} \mathrm{~cm} / \mathrm{s}$ at $11.84 \mathrm{~nL} / \mathrm{min}(p$ NS). The permeability

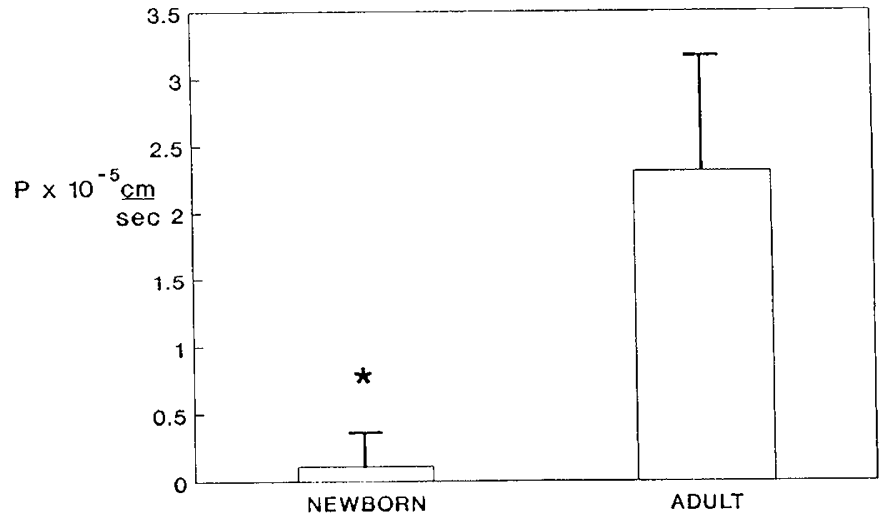

p 0.05

Fig. 3. Bicarbonate permeability in neonatal and adult JMPCT perfused at $10 \mathrm{~nL} / \mathrm{min}$ and $38^{\circ} \mathrm{C}(p<0.05)$.

in neonatal PCT actually decreased at the faster perfusion rate. This apparent decrease in permeability could be due to the small inaccuracy of measuring bicarbonate with the method used and the small bicarbonate permeability in the neonate. The collected bicarbonate concentration at the fast perfusion rate in neonatal PCT was $4.7 \mathrm{mmol} / \mathrm{L}$. With the methods used, this would not be distinguishable from $4.9 \mathrm{mmol} / \mathrm{L}$, which is the expected collected bicarbonate concentration if the bicarbonate permeability remains constant.

Apical proton secretion by the proximal tubule is primarily via the $\mathrm{Na}^{+} / \mathrm{H}^{+}$antiporter and bicarbonate exit via the $\mathrm{Na}\left(\mathrm{HCO}_{3}\right)_{3}$ symporter. The energy for proton secretion via the $\mathrm{Na}^{+} / \mathrm{H}^{+}$antiporter is derived from the lumen of cell $\mathrm{Na}^{+}$concentration gradient. The low intracellular sodium concentration is maintained by the basolateral $\mathrm{Na}^{+} / \mathrm{K}^{+}$-ATPase. All of these transport processes have recently been shown to undergo maturation in the neonate. Baum (15) recently investigated the maturation of the $\mathrm{Na}^{+} / \mathrm{H}^{+}$antiporter and the $\mathrm{Na}\left(\mathrm{HCO}_{3}\right)_{3}$ symporter using fluorescent measurements of intracellular $\mathrm{pH}$ in rabbit JMPCT. By changing the luminal $\mathrm{Na}^{+}$concentration from 147 to $0 \mathrm{mmol} / \mathrm{L}$, the proton secretory rate of the $\mathrm{Na}^{+} / \mathrm{H}^{+}$antiporter in the neonatal PCT was found to be $1 / 3$ that of the adult PCT. The activity of the neonatal basolateral $\mathrm{Na}\left(\mathrm{HCO}_{3}\right)_{3}$ symporter was $1 / 2$ the adult rate. Thus, both the apical $\mathrm{Na}^{+} / \mathrm{H}^{+}$antiporter and the basolateral $\mathrm{Na}\left(\mathrm{HCO}_{3}\right)_{3}$ symporter responsible for active $\mathrm{HCO}_{3}^{-}$transport are immature at birth.

Schmidt and Horster (16) and Schwartz and Evan (17) have shown that the basolateral $\mathrm{Na}^{+} / \mathrm{K}^{+}$-ATPase also increases with maturation. Schmidt and Horster (16) found the activity in the neonatal PCT $\mathrm{Na}^{+} / \mathrm{K}^{+}$-ATPase to be $1 / 3$ the adult value in JMPCT and $1 / 2$ the adult value in superficial PCT. Schwartz and Evan (17) found that $\mathrm{Na}^{+} / \mathrm{K}^{+}$-ATPase activity in neonatal JMPCT was $1 / 3$ that measured in adult JMPCT. The $\mathrm{Na}^{+} / \mathrm{K}^{+}$-ATPase 
activity increased during the first $6 \mathrm{wk}$ of age, and reached adult rates after the 7 th wk of life (17).

The paracellular leak pathway for bicarbonate remains to be investigated. A high bicarbonate permeability in the neonatal PCT could also contribute to the reduced rate of transepithelial bicarbonate transport. Our study examined bicarbonate permeability across the adult and neonatal PCT. Although bicarbonate absorption in the PCT is transcellular, bicarbonate back-leak is across the paracellular pathway. The lower bicarbonate permeability in neonatal PCT could be due to either a lower permeability of this pathway for bicarbonate diffusion or a smaller area for diffusion. Indeed, it is possible that the permeability of the pathway for diffusion in neonates is higher than that in adults, but the area for diffusion is much smaller. This was not addressed by our data. This in vitro microperfusion study directly demonstrates that the bicarbonate permeability of neonatal JMPCT is much lower than that of adult JMPCT. This reduction in the permeability may be responsible for maintaining the bicarbonate concentration gradient that is generated by transport processes that are functioning below the adult level.

Acknowledgments. The authors thank Rebecca Aricheta and Ebtisam Shawky for their technical assistance and Janell McQuinn for her able secretarial assistance.

\section{REFERENCES}

1. Dubose Jr TD, Pucacco LR, Lucci MS, Carter NW 1979 Micropuncture determination of $\mathrm{pH}, \mathrm{PCO}_{2}$, and total $\mathrm{CO}_{2}$ concentration in accessible structures of the rat renal cortex. J Clin Invest 64:476-482

2. Edelmann Jr CM, Soriano JR, Boichis H, Gruskin AB, Acosta MI 1967 Renal bicarbonate reabsorption and hydrogen ion excretion in normal infants. $J$ Clin Invest 46:1309-1317

3. Schwartz GJ, Evan AP 1983 Development of solute transport in rabbit proximal tubule. I. $\mathrm{HCO}_{3}^{-}$and glucose absorption. Am J Physiol 245(14):F382F390

4. Kaskel FJ, Kumar AM, Lockhart EA, Evan A, Spitzer A 1987 Factors affecting proximal tubular reabsorption during development. Am J Physiol 252(21):F188-F197

5. Baum M 1987 Insulin stimulates volume absorption in the rabbit proximal convoluted tubule. J Clin Invest 79:1104-1109

6. Salmon RF, Baum M 1990 Intracellular cystine loading inhibits transport in the rabbit proximal convoluted tubule. J Clin Invest 85:340-344

7. Liu FY, Cogan MG 1987 Kinetics of bicarbonate transport in the early proximal convoluted tubule. Am J Physiol 253(22):F912-F916

8. Vurek GG, Warnock DG, Corsey R 1975 Measurement of picomole amounts of carbon dioxide by calorimetry. Anal Chem 47:765-767

9. Sasaki S, Berry CA, Rector Jr FC 1982 Effect of luminal and peritubular $\mathrm{HCO}_{3}^{-}$concentrations and $\mathrm{PCO}_{2}$ on $\mathrm{HCO}_{3}^{-}$reabsorption in rabbit proximal convoluted tubules perfused in vitro. J Clin Invest 70:639-649

10. Spitzer A, Brandis M 1974 Functional and morphologic maturation of the superficial nephrons relationship to total kidney function. J Clin Invest 53:279-287

11. Horster M 1985 Ontogenetic processes in nephron epithelia: function, enzymes, and structure. In: Seldin DW, Giebisch G (eds) The Kidney: Physiology and Pathophysiology. Raven Press, New York, p 323

12. Liu FY, Cogan MG 1988 Angiotensin II stimulation of hydrogen ion secretion in the rat early proximal tubule modes of action, mechanism, and kinetics. J Clin Invest 82:601-607

13. Liu FY, Cogan MG 1988 Flow dependence of bicarbonate transport in the early $\left(S_{1}\right)$ proximal convoluted tubule. Am J Physiol 254(23):F851-F855

14. Holmberg C, Kokko JP, Jacobson HR 1981 Determination of chloride and bicarbonate permeabilities in proximal convoluted tubules. Am J Physio 241(10):F386-F394

15. Baum M 1990 Neonatal rabbit juxtamedullary proximal convoluted tubule acidification. J Clin Invest 85:499-506

16. Schmidt U, Horster M $1977 \mathrm{Na}-\mathrm{K}$-activated ATPase: activity maturation in rabbit nephron segments dissected in vitro. Am J Physiol 233(2):F55-F60

17. Schwartz GJ, Evan AP 1984 Development of solute transport in rabbit proximal tubule. III. Na-K-ATPase activity. Am J Physiol 246(15):F845-F852 